Materials Issues in Semiconducto

\title{
ULTRA HIGH TEMPERATURE RAPID THERMAL ANNEALING OF GaN
}

X. A. Cao ${ }^{(1)}$, R. K. Singh ${ }^{(1)}$, S. J. Pearton ${ }^{(1)}$, M. Fu ${ }^{(2)}$, J. A. Sekhar ${ }^{(2)}$, R. G. Wilson $^{(3)}$, J. C. Zolper ${ }^{(4)}$, J. $\operatorname{Han}^{(5)}$, D. J. Rieger ${ }^{(5)}$ and R. J. Shul ${ }^{(5)}$

${ }^{(1)}$ Department of Materials Science and Engineering, University of Florida, Gainesville, FL 32611 USA

(2) Micropyretics Heaters International, Inc. Cincinnati, OH 45212 USA

${ }^{(3)}$ Consultant, Stevenson Ranch, CA 91381 USA

${ }^{4}$ Office of Naval Research, Arlington, VA 22217 USA

${ }^{(5)}$ Sandia National Laboratories, Albuquerque, NM 87185 USA

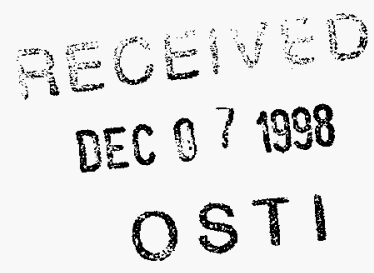

\section{ABSTRACT}

All of the major acceptor $(\mathrm{Mg}, \mathrm{C}, \mathrm{Be})$ and donor $(\mathrm{Si}, \mathrm{S}, \mathrm{Se}$ and $\mathrm{Te})$ dopants have been implanted into $\mathrm{GaN}$ films grown on $\mathrm{Al}_{2} \mathrm{O}_{3}$ substrates. Annealing was performed at 1100 $1500{ }^{\circ} \mathrm{C}$, using AlN encapsulation. Activation percentages of $\geq 90 \%$ were obtained for $\mathrm{Si}^{+}$ implantation annealed at $1400{ }^{\circ} \mathrm{C}$, while higher temperatures led to a decrease in both carrier concentration and electron mobility. No measurable redistribution of any of the implanted dopants was observed at $1450^{\circ} \mathrm{C}$. 


\section{INTRODUCTION}

The use of selective area implantation to create channel and/or contact regions is the basis of standard metal semiconductor field effect transistor (MESFET) technology in GaAs, and a similar process is desirable for GaN slectronics. ${ }^{(1,2)}$ Currently, most GaNbased electronic devices for high power, high frequency, high temperature applications are heterostructure FETs, ${ }^{(3-7)}$ and for these devices implantation is also useful for increasing doping in the source/drain regions for improved contact resistance. ${ }^{(8)}$

Past work has shown that anneal temperatures of $1100-1150{ }^{\circ} \mathrm{C}$ produce reasonably good activation efficiencies for $\mathrm{Si}^{+}$or $\mathrm{Mg}^{+}$implant doses up to $\sim 10^{14} \mathrm{~cm}^{-2} \cdot{ }^{(8-11)}$ However considerable lattice damage remains for higher dose implants annealed at these temperatures, producing a clear need for furnaces capable of $1400-1500{ }^{\circ} \mathrm{C}^{(11-16)}$ Conventional rapid thermal processing(RTP) systems generally reach a maximum temperature of $\sim 1300^{\circ} \mathrm{C}$. It is desirable that the time at elevated temperature be minimized because of the high vapor pressure of $\mathrm{N}_{2}$ above $\mathrm{GaN}$ and the need to prevent dissociation of the surface. ${ }^{(17,18)}$ Several different surface protection schemes have been reported for high temperature annealing of $\mathrm{GaN}$, including provision of $\mathrm{NH}_{3}$ ambients, high pressure $\mathrm{N}_{2}$ ambients, AlN encapsulation or use of granulated $\mathrm{InN}$ or $\mathrm{GaN}$ powder within the reservoirs of a graphite susceptor in which the implanted sample is contained. ${ }^{(19,20)}$ In terms of utility in a fabrication line, the AlN cap approach seems the most effective. The AlN can be deposited by reactive sputtering and selectively removed after the annealing processing by $\mathrm{KOH}$ etching. ${ }^{(21)}$

In this paper we describe the use of a novel high temperature RTP system for annealing of implanted $\mathrm{GaN}$ at temperatures up to $1500^{\circ} \mathrm{C}$. Extremely good activation 


\section{DISCLAIMER}

This report was prepared as an account of work sponsored by an agency of the United States Government. Neither the United States Government nor any agency thereof, nor any of their employees, make any warranty, express or implied, or assumes any legal liability or responsibility for the accuracy, completeness, or usefulness of any information, apparatus, product, or process disclosed, or represents that its use would not infringe privately owned rights. Reference herein to any specific commercial product, process, or service by trade name, trademark, manufacturer, or otherwise does not necessarily constitute or imply its endorsement, recommendation, or favoring by the United States Government or any agency thereof. The views and opinions of authors expressed herein do not necessarily state or reflect those of the United States Government or any agency thereof. 


\section{DISCLAIMER}

Portions of this document may be illegible in electronic image products. Images are produced from the best available original document. 
efficiencies for $\mathrm{Si}^{+}$implants were obtained $(\geq 90 \%)$, while little redistribution was observed for all the common donors $(\mathrm{Si}, \mathrm{S}, \mathrm{Se}, \mathrm{Te})$ and acceptor( $\mathrm{Mg}, \mathrm{C}, \mathrm{Be})$ species.

\section{EXPERIMENTAL}

Epitaxial GaN layers 2-3 $\mu \mathrm{m}$ thick were grown on c-axis $\mathrm{Al}_{2} \mathrm{O}_{3}$ substrates at $\sim 1040$ ${ }^{\circ} \mathrm{C}$ by Metal Organic Chemical Vapor Deposition. The layers were nominally undoped $\left(\mathrm{n}=1-8 \times 10^{16} \mathrm{~cm}^{-3}\right)$. Implantation of $\mathrm{Si}^{+}, \mathrm{S}^{+}, \mathrm{Se}^{+}, \mathrm{Te}^{+}, \mathrm{Be}^{+}, \mathrm{C}^{+}$or $\mathrm{Mg}^{+}$ions was performed at $25^{\circ} \mathrm{C}$, at doses of $1-5 \times 10^{15} \mathrm{~cm}^{-2}$ and energies designed to place the projected range at 1200-1500 $\AA$. The samples were deposited with $1000 \AA$ of AlN by reactive sputtering.

Annealing was performed in an MHI Zapper RTP furnace, which employs molybdenum intermetallic composite heating elements. These are maintained at constant temperature with the sample inserted and removed via a motor-driven actuator to achieve high ramp-up and ramp-down rates. Annealing was performed at $1100-1500^{\circ} \mathrm{C}$ for dwell times of 10 secs. Typical time-temperature profiles for 1400 and $1500{ }^{\circ} \mathrm{C}$ are shown in

Figure 1. After annealing the AlN was removed by etching in $0.1 \mathrm{M} \mathrm{KOH}$ solution at 70 ${ }^{\circ} \mathrm{C}$. The electrical properties of the $\mathrm{Si}^{+}$implanted samples were obtained from Van der Pauw geometry Hall measurements using HgIn contacts alloyed at $420^{\circ} \mathrm{C}$ for 3 mins. Redistribution of the implanted species was examined by performing Secondary Ion Mass Spectrometry (SIMS) using a Cameca system.

\section{RESULTS AND DISCUSSION}

Figure 2 shows an Arrhenius plot of sheet carrier concentration in $\mathrm{Si}^{+}$implanted material. In the AIN encapsulated samples activation occurs with an activation energy of 
$\sim 5.2 \mathrm{eV}$ before saturating at $\sim 1400^{\circ} \mathrm{C}$. We interpret this activation energy as the average required to move the interstitial $\mathrm{Si}$ atom to a vacant substitutional site by short-range diffusion and to simultaneously remove compensating point defects so that the $\mathrm{Si}$ is electrically active. Note that at $1500^{\circ} \mathrm{C}$ the sheet electron density decreases, and this was accompanied by a decrease in carrier mobility. This increase in compensation is consistent with Si beginning to occupy both $\mathrm{Ga}$ sites(where it is a donor), and $\mathrm{N}$ sites(where it is an acceptor). This is commonly observed with Si implantation in other III-V materials. ${ }^{(22)}$ The peak n-type doping level we obtained is $\sim 5 \times 10^{20} \mathrm{~cm}^{-3}$. This high carrier concentration enhances emission over the barrier on metal contacts deposited on the material. For example, for both $\mathrm{W}$ and $\mathrm{WSi}_{\mathrm{x}}$ sputter deposited on Si-implanted material activated by annealing, we obtained specific contact resistances of $\sim 10^{-6} \Omega \cdot \mathrm{cm}^{2}$ after annealing in the range $600-900^{\circ} \mathrm{C}$. This combination is particularly effective for producing high quality, stable ohmic contacts on $\mathrm{GaN}$, since there is no measurable reaction of the $\mathrm{W}$ or $\mathrm{WSi}_{\mathrm{x}}$ with the semiconductor at $900^{\circ} \mathrm{C}$. This is superior to the more commonly employed $\mathrm{Ti} / \mathrm{Al}$ and $\mathrm{Ni} / \mathrm{Au}$ metallizations on $\mathrm{GaN}$.

$\mathrm{Si}^{+}$implantation produces the best n-type doping of $\mathrm{GaN}$, but there is also interest in the group VI donors: S, Se and Te. From preliminary measurements, we obtained $\leq 40 \%$ activation for these dopants under the same conditions that produced $90 \%$ activation with Si. There was basically no redistribution of any of the dopants to $1450{ }^{\circ} \mathrm{C}$; given the resolution of the SIMS measurements, this indicates that the diffusivity for each of these elements at $1450^{\circ} \mathrm{C}$ is $\leq 10^{-13} \mathrm{~cm}^{2} \cdot \mathrm{s}^{-1}$. These are clearly the lowest diffusivities of these elements in any compound semiconductor, and emphasize the stable nature of implanted GaN devices. Figure 3 shows the data for $\mathrm{S}^{+}$implants. In a similar fashion, the atomic 
profiles of $\mathrm{Mg}, \mathrm{C}$ and $\mathrm{Be}$ were measured before and after annealing at $1450^{\circ} \mathrm{C}$, there was no detectable redistribution for $\mathrm{Mg}$ and $\mathrm{C}$. Figure 4 shows the data for $\mathrm{Mg}^{+}$implants. Thus, the diffusivities of these acceptor species are also $\leq 10^{-13} \mathrm{~cm}^{2} \cdot \mathrm{s}^{-1}$ at $1450^{\circ} \mathrm{C}$. For $\mathrm{Be}$, a slight amount of diffusion was observed at $900^{\circ} \mathrm{C}(\sim 300 \AA$ at full-width-halfmaximum), but no motion at higher temperatures. This is consistent with defect-assisted motion of the Be, which ceases once the implant damage is annealed.

\section{SUMMARY AND CONCLUSIONS}

The most common acceptor and donor dopants have been implanted into $\mathrm{GaN}$, and annealed at $1100-1500{ }^{\circ} \mathrm{C}$ for dwell times of 10 secs at the peak temperatures. No measurable redistribution was observed for any of the implanted species at $1450^{\circ} \mathrm{C}$. AlN has proven to be an effective encapsulant at these high temperatures, and can be selectively removed in $\mathrm{KOH}$ solutions, there was no evidence of interdiffusion between the AIN and GaN. Annealing at $1400{ }^{\circ} \mathrm{C}$ produced the highest activation for implanted $\mathrm{Si}(\sim 90 \%)$, while higher temperatures led to an increase in self compensation.

\section{ACKNOWLEDGEMENTS}

The work of UF is partially supported by grants from NSF-DMR (L. Hess), DARPA/EPRI (E. R. Brown/J. Melcher) and a sub-contract from MHI, who are supported by a BMDO SBIR grant (F19628-97-C-0092) monitored by Dr. Joe Lorenzo. R. G. Wilson is partially supported by a grant from ARO (Dr. J. M. Zavada). Sandia is a multiprogram laboratory, operated by Sandia Corporation, a Lockheed-Martin company, for the US Department of Energy under contract No. DE-AC04-94 AL 85000. 


\section{References}

1. See for example, J. C. Zolper, in GaN and Related Materials (Gordon and Beach, NY 1997).

2. J. C. Zolper and R. J. Shul, MRS Bulletin 2236 (1997).

3. S. C. Binari, L. B. Rowland, W. Kruppa, G. Kelner, K. Doverspike and D. K. Gaskill, Electron. Lett. 301248 (1994).

4. J. Burm, K. Chu, W. A. Davis, W. J. Schaff, L. F. Eastman and T. J. Eustis, Appl. Phys. Lett. 70464 (1997).

5. Q. Chen, M. A. Khan, J. W. Yang, C. J. Sun, M. S. Shur and H. Park, Appl. Phys. Lett. $\underline{69} 794$ (1996).

6. Y. -F. Wu, B. P. Keller, S. Keller, D. Kapolnek, P. Kozodoy, S. P. DenBaars and U. K. Mishra, Appl. Phys. Lett. 691438 (1996).

7. N. X. Nguyen, B. P. Keller, S. Keller, Y. F. Wu, M. Le, C. Nguyen, S. P. DenBaars, U. K. Mishra and D. Grider, Electron. Lett. $\underline{33} 334$ (1997).

8. J. C. Zolper, R. J. Shul, A. G. Baca, R. G. Wilson, S. J. Pearton and R. A. Stall, Appl. Phys. Lett. $\underline{68} 2273$ (1996).

9. J. C. Zolper, M. H. Crawford, S. J. Pearton, C. R. Abernathy, C. B. Vartuli, C. Yuan and R. A. Stall, J. Electron. Mater. $\underline{25} 839$ (1996).

10. S. J. Pearton, C. R. Abernathy, C. B. Vartuli, J. C. Zolper, C. Yuan and R. A. Stall, Appl. Phys. Lett. 671435 (1995).

11. J. C. Zolper, R. G. Wilson, S. J. Pearton and R. A. Stall, Appl. Phys. Lett. $\underline{68} 1945$ (1996). 
12. H. H. Tan, J. S. Williams, J. Zou, D. J. H. Cockayne, S. J. Pearton and R. A. Stall, Appl. Phys. Lett. $\underline{69} 2364$ (1996).

13. J. C. Zolper, M. H. Crawford, H. H. Tan, J. S. Williams, J. Zou, D. J. H. Cockayne, S. J. Pearton and R. F. Karlicek, Appl. Phys. Lett. 702729 (1997).

14. S. Strite, P. W. Epperlein, A. Dommen, A. Rockett and R. F. Broom, Mat. Res. Soc. Symp. Proc. $\underline{395} 795$ (1996).

15. N. Parikh, A. Suvkhanov, M. Lioubtchenko, E. Carlson, M. Bremser, D. Bray, R. Davis and J. Hunn, Nucl. Instr. Meth. B $\underline{127 / 128} 463$ (1997).

16. J. C. Zolper, J. Han, R. M. Biefeld, S. B. Van Deusen, W. R. Wampler, D. J. Reiger, S. J. Pearton, J. S. Williams, H. H. Tan and R. Stall, J. Electron. Mater. 27179 (1998).

17. S. Porowski and I. Grzegory, in GaN and Related Materials, ed. S. J. Pearton (Gordon and Breach, NY 1997).

18. N. Newman, In GaN, Vol. I, ed. J. Pankove and T. D. Moustakas (Academic Press, NY 1998).

19. J. Hong. J. W. Lee, J. D. MacKenzie, S. M. Donovan, C. R. Abernathy, S. J. Pearton and J. C. Zolper, Semicon. Sci. Technol. 121310 (1997).

20. J. C. Zolper, D. J. Reiger, A. G. Baca, S. J. Pearton, J. W. Lee and R. A. Stall, Appl. Phys. Lett. $\underline{69} 538$ (1996).

21. J. R. Mileham, S. J. Pearton, C. R. Abernathy, J. D. MacKenzie, R. J. Shul and S. P. Kilcoyne, Appl. Phys. Lett. 671119 (1995).

22. S. J. Pearton, J. S. Williams, K. T. Short, S. T. Johnson, D. C. Jacobsen, J. M. Poate, J. M. Gibson and D. O. Boerma, J. Appl. Phys. $\underline{65} 1089$ (1989). 


\section{Figure Captions}

Figure 1. Time-temperature profiles for $10 \mathrm{sec}$ anneals at both 1400 and $1500^{\circ} \mathrm{C}$.

Figure 2. Arrhenius plot of sheet electron concentration versus inverse anneal temperature for $\mathrm{Si}^{+}$implanted $\mathrm{GaN}$..

Figure 3. SIMS profiles of $200 \mathrm{keV} \mathrm{S}^{+}$implants in $\mathrm{GaN}$ before and after annealing at $1450{ }^{\circ} \mathrm{C}$ for 10 secs.

Figure 4. SIMS profiles of $150 \mathrm{keV} \mathrm{Mg}^{+}$implants in $\mathrm{GaN}$ before and after annealing at $1450{ }^{\circ} \mathrm{C}$ for 10 secs. 

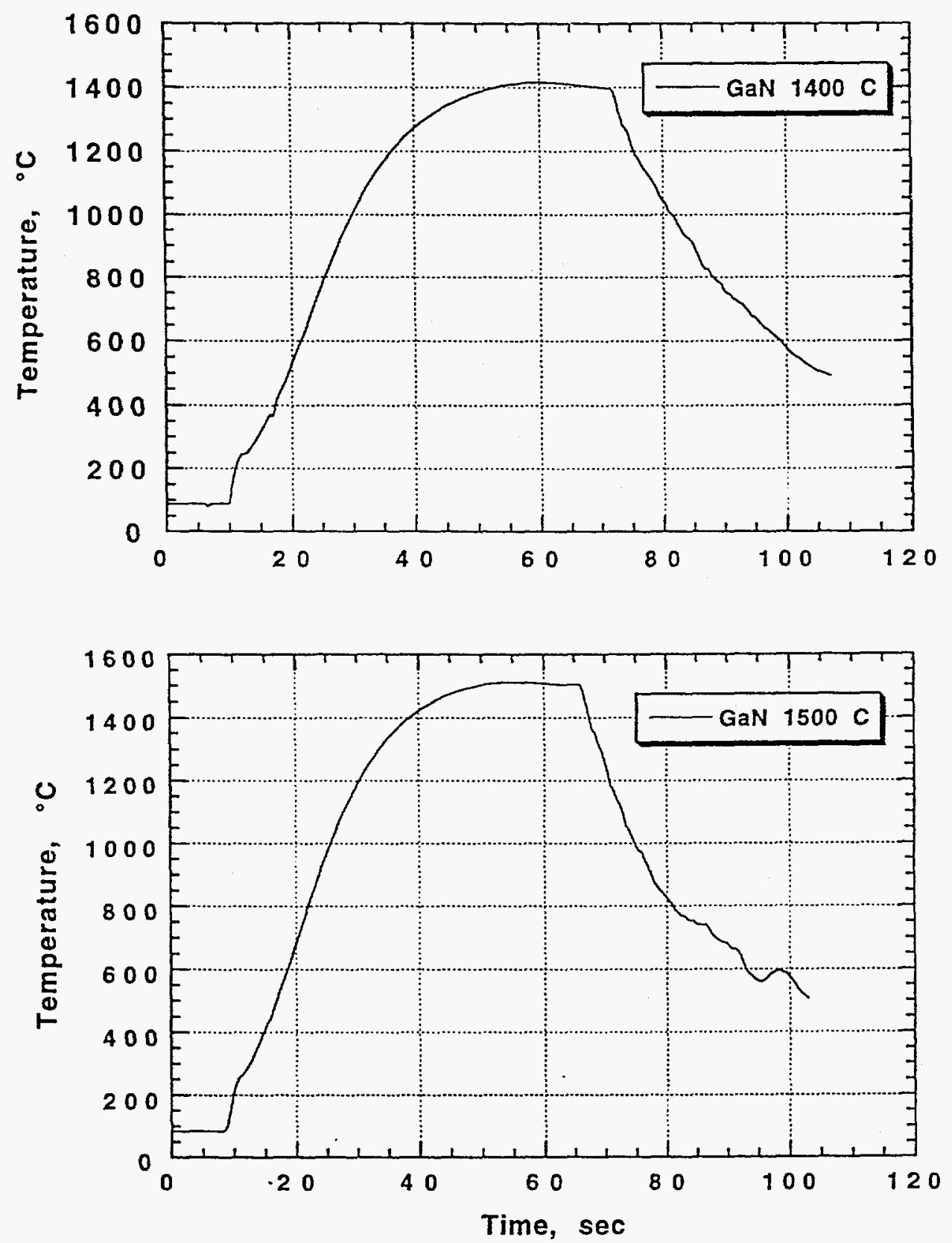


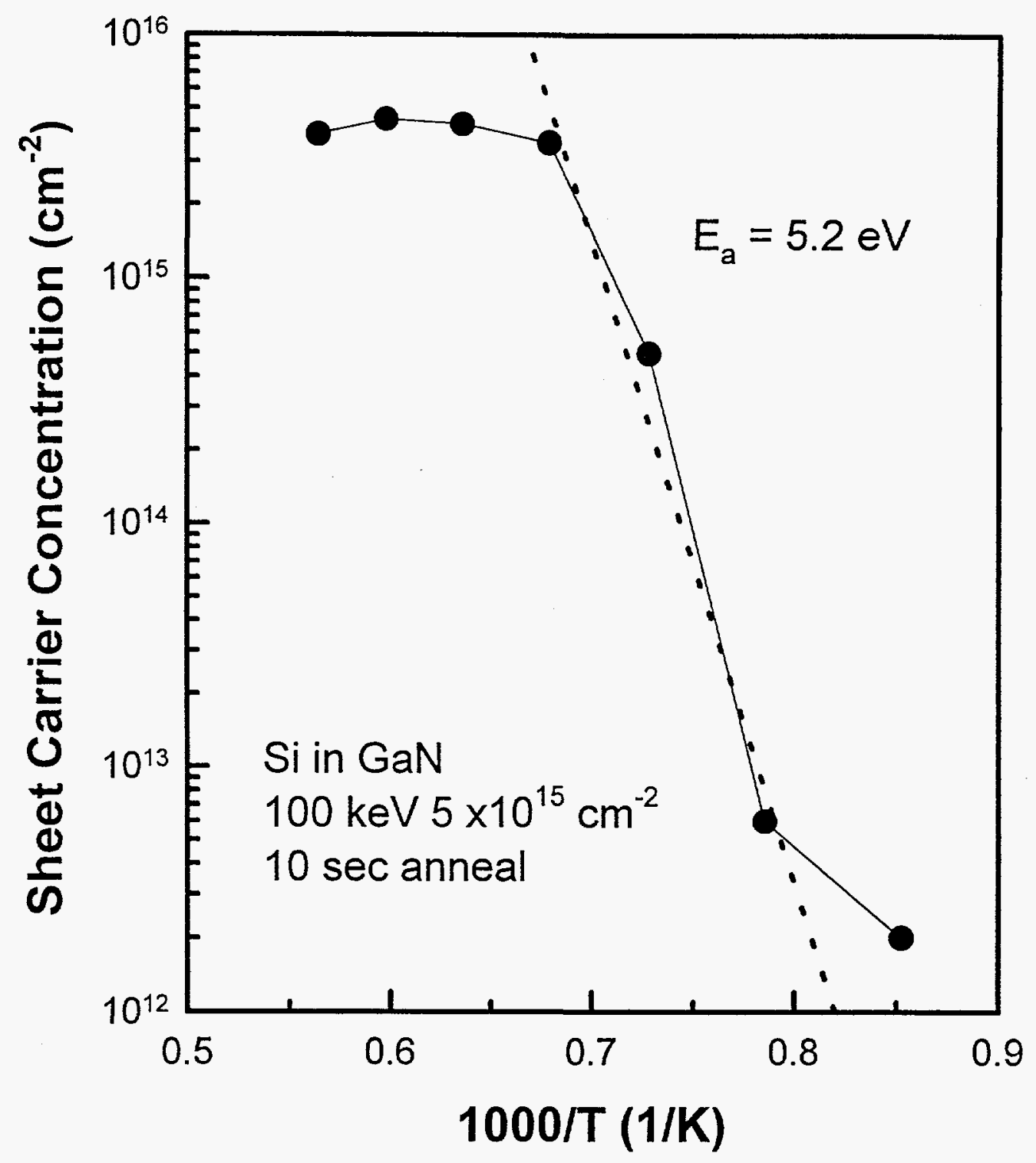




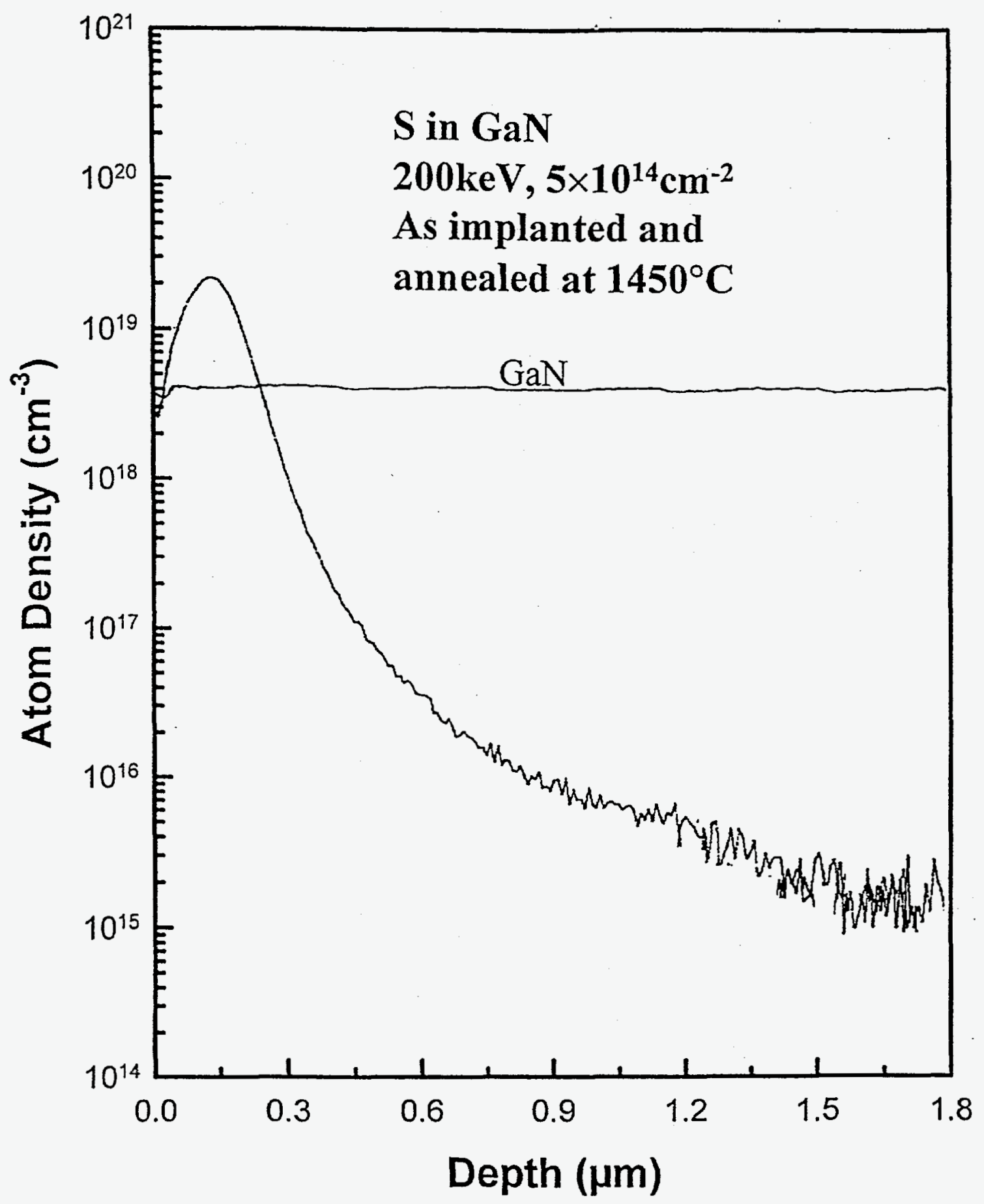




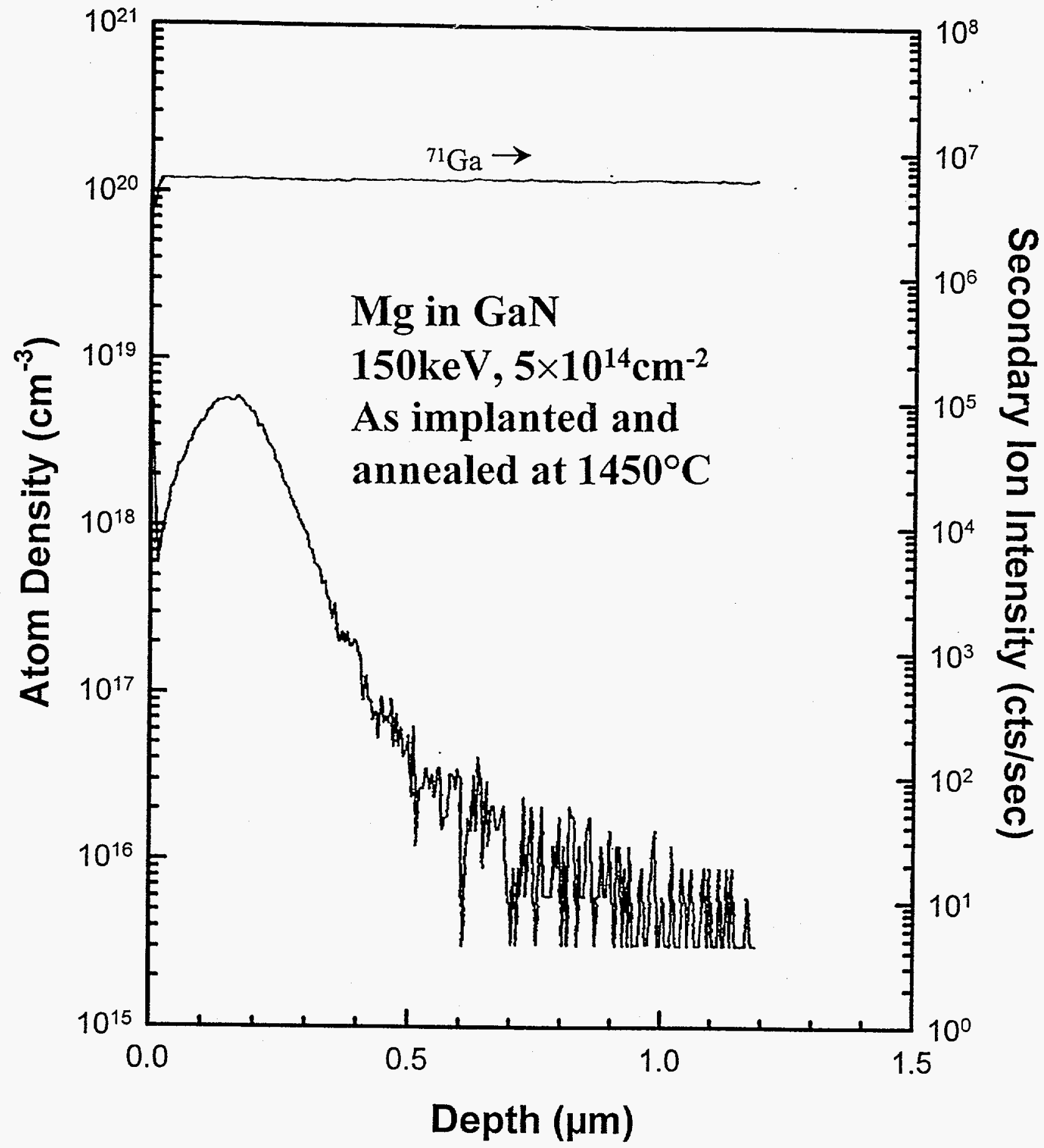

